\title{
DESALINATION
}

Desalination 164 (2004) 173-188

wwwelseviercom/locateldesal

\section{A new methodology for removal of boron from water by coal and fly ash}

\author{
H. Polat ${ }^{\mathrm{a}}$, A. Vengosh ${ }^{\mathrm{b} *}$, I. Pankratov ${ }^{\mathrm{b}}$, M. Polat ${ }^{\mathrm{c}}$ \\ aDepartment of Chemistry, Izmir Institute of Technology, 35430 Urla-Izmir, Turkey \\ ${ }^{b}$ Department of Geological and Environmental Sciences, Ben-Gurion University, \\ P.O. Box 653, Beer-Sheva 84105, Israel \\ Tel.+972 (8) 647-7504; Fux +972 (8) 647-2997; email: avnerv@bgumail.bgu.ac.il \\ 'Department of Chemical Engineering, Izmir Institute of Technology, 35430 Urla-Izmir, Turkey
}

Received 10 July 2003; accepted 12 September 2003

\begin{abstract}
High levels of boron concentrations in water present a serious problem for domestic and agriculture utilizations. The recent $\mathrm{EU}$ drinking water directive defines an upper limit of $1 \mathrm{mgB} / \mathrm{l}$. In addition, most crops are sensitive to boron levels $>0.75 \mathrm{mg} / \mathrm{l}$ in irrigation water. The boron problem is magnified by the partial $(\sim 60 \%)$ removal of boron in reverse osmosis (RO) desalination due to the poor ionization of boric acid and the accumulation of boron in domestic sewage effluents. Moreover, high levels of boron are found in regional groundwater in some Mediterranean countries, which requires special treatment in order to meet the EU drinking water regulations. Previous attempts to remove boron employed boron-specific ion-exchange resin and several cycles of $\mathrm{RO}$ desalination under high $\mathrm{pH}$ conditions. Here, we present an alternative methodology for boron removal by using coal and fly ash as adsorbents. We conducted various column and batch experiments that explored the efficiency of boron removal from seawater and desalinated seawater using several types of coal and fly ash materials under controlled conditions ( $\mathrm{pH}$, liquid/solid ratio, time of reaction, pre-treatment, regeneration). We examined the effect of these factors on the boron removal capacity and the overall chemical composition of the residual seawater. The results show that the selected coal and fly ash materials are very effective in removing boron such that the rejection ratio of boron can reach $95 \%$ of the initial boron content under certain optimal conditions (e.g., $\mathrm{pH}=9, \mathrm{~L} / \mathrm{S}=1 / 10$, reaction time $>6 \mathrm{~h}$ ). Our experiments demonstrated that use of glycerin enables regeneration of boron uptake into coal, but the boron uptake capacity of fly ash reduces after several cycles of treatment-reaction. The boron removal is associated with $\mathrm{Mg}$ depletion and $\mathrm{Ca}$ enrichment in the residual seawater and conversely with relative $\mathrm{Mg}$ enrichment and Ca depletion in the residual fly ash. We propose that the reaction of Ca-rich fly ash with $\mathrm{Mg}$-rich seawater causes co-precipitation of magnesium hydroxide in which boron is co-precipitated. The new methodology might provide an alternative technique for boron removal in areas where coal and fly ash are abundant.
\end{abstract}

Keywords: Boron; Coal; Fly ash; Reverse osmosis; Mg-oxide; Water treatment; Seawater

*Corresponding author.

0011-9164/04/\$- See front matter (C) 2004 Elsevier B.V. All rights reserved

PII: S0011-9164(04)00176-6 


\section{Introduction}

Water stress in the arid and semi-arid regions results from a combination of natural climatic conditions, high human pressures, and often poor water management structures. In many regions, worldwide, water resources frequently suffer from severe salinisation problems that endanger present and future exploitation and consequently economic and social developments. One of the inorganic constituents that are problematic and difficult to get rid of is boron. High levels of boron are found in seawater $(4.7 \mathrm{mg} /)$, domestic wastewater $(0.5-$ $2 \mathrm{mg} / \mathrm{l}$ ), and regional groundwater (e.g., Italy, Cyprus and Greece with boron content up to $8 \mathrm{mg} / \mathrm{l}$ ). The World Health Organization defines boron level of $0.3 \mathrm{mg} / \mathrm{l}$ as the non-observed effect level (NOEL) for drinking water [1]. High boron levels in drinking water can be toxic to humans as boron has been shown to cause male reproductive impediments in laboratory animals [2-4]. Recently boron has been classified by the European Union as a pollutant of drinking water in national and international drinking water directives (EU Council Directive 98/83/EC: $1 \mathrm{mg} / \mathrm{l}$ ). Moreover, boron is a unique micronutrient in which overdose and under-dose of boron supply cause toxicity and deficiency symptoms in plants, respectively. The level of boron in irrigation water exceeding $1 \mathrm{mg} / \mathrm{l}$ can affect the yield of sensitive crops (e.g., avocado, citrus fruits).

The boron problem is magnified by the fact that neither standard wastewater treatment nor desalination of seawater by reverse osmosis (RO) can bring about its successful elimination from the raw water. Like other inorganic ions, boron is not removed during standard sewage treatment processes [5]. Moreover, owing to the predominance of the non-charged boric acid in the solution, only a fraction of the boron $(\sim 60 \%)$ is removed during reverse osmosis (RO) desalination [6-10]. Thus, even RO desalted seawater contains high level of boron $(\sim 1.7 \mathrm{mg} / \mathrm{l})$ above the maximum admissible international values. In addition, future manage- ment scenarios in water-stress areas consider recycling of RO-desalination, wastewater treatment, and irrigation with treated waste water as a mechanism to overcome the water shortage. The high boron levels that are associated their recycling stages overshadow, however, implementation of such a scenario. In low-level radioactive waste, boron (as ${ }^{10} \mathrm{~B}$ ) is also used to prevent fission of radionuclides by adsorbing free neutrons. After most of radiation is decayed, boron still remains in the waste and limits its burial in landfill sites [11].

Previous attempts to remove boron from water were primarily based on boron specific ionexchange and second-cycle of RO desalination, yet these solutions add significant cost to the overall treatment technique [8]. The boronspecific ion-exchange resin (Amberlite IRA-743) has the capacity of almost $100 \%$ removal of boron under high $\mathrm{pH}$ conditions [12-15] and is used to remove boron from high-boron effluents in Turkey [16-18]. The use of this method for complementary RO desalination adds additional cost of US cent $4-6 / \mathrm{m}^{3}$ of permeate [8]. In contrast, RO removes only a fraction of boron, between 40 $65 \%$ [6-10]. However, a second-stage RO desalination under high $\mathrm{pH}$ condition increases boron rejection to $92 \%$ [10]. Other tested method of boron treatment is electrodialysis, which is capable of removing $40-75 \%$ and even increase to $88 \%$ under high $\mathrm{pH}$ conditions [19].

Here we present an alternative methodology of boron removal using natural coal and fly ash materials. Previous studies showed that boron is one of the most mobile elements in ash disposal system and a large fraction of boron in fly ash is leached with water, particularly under low $\mathrm{pH}$ conditions [20-25], In contrast, this paper shows that boron can also be retained by coal and fly ash. We performed several series of column and batch experiments that tested the removal capacity and the conditions that control boron retention from seawater. The results show a significant reduction of boron concentration in seawater after interaction with different types of coal and fly ash. 


\section{Experimental methods}

\subsection{Materials}

The lignite coal samples were obtained from Yenikoy, Western Turkey (Table 1). One fly ash sample came from the Rutenberg Power Plant of the Israel Electric Corporation (IEC) in Ashkelon, which combusts South African bituminous coal. This coal has an ash content of $13.9 \%$ and accounted for $60 \%$ of the total ash generation in Israel. Three fly ash samples from the Soma, Yenikoy and

Table 1

Some properties of the Yenicoy coal sample

\begin{tabular}{ll}
\hline kcal/kg & 1750 \\
Moisture, \% & 33.00 \\
Ash, \% & 29.0 \\
Total sulfur, \% & $2.7-5.96$ \\
Fixed carbon & 20.5 \\
Volatile matter & Min 25 \\
\hline
\end{tabular}

Yatagan from power plants in Turkey were also used in this study. These power plants, which burn very low calorie lignite coals with ash contents ranging between $40-50 \%$ (Table 1), are responsible for about $40 \%$ of the total ash generated in Turkey. The composition of the fly ash for the major and trace elements are given in Table 2. Coal samples were crushed to $1200 \mu \mathrm{m}$. Fly ash samples were used as they were recovered from industrial coal combustion. Seawater collected from the Gulf of Elat (Red Sea) and from the Mediterranean Sea (Table 3). Desalinated seawater from the desalination plant in Elat was also used in some of the experiments.

\subsection{Procedures}

Boron removal tests were carried out in columns $(10 \mathrm{~cm}$ length, $1 \mathrm{~cm}$ in diameter) and batch experiments. A peristaltic pump was used in the column experiments in order to maintain

Table 2

Composition of Soma, Yatagan, Yenikoy and South African fly ashes for majors and trace elements

\begin{tabular}{lcccc}
\hline Element & Soma & Yatagan & Yenikoy & S. African \\
\hline $\mathrm{CaO}, \%$ & 33.77 & 23.51 & 38.24 & 8.35 \\
$\mathrm{SiO}_{2}, \%$ & 33.41 & 36.43 & 20.79 & 40.9 \\
$\mathrm{Al}_{2} \mathrm{O}_{3}, \%$ & 16.13 & 16.13 & 17.26 & 31.4 \\
$\mathrm{Fe}_{2} \mathrm{O}_{3} \%$ & 6.00 & 7.77 & 7.17 & 3.05 \\
$\mathrm{MgO} \%$ & 6.07 & 8.80 & 4.66 & 2.45 \\
$\mathrm{SO}_{3} \%$ & 2.80 & $\mathrm{NA}$ & 12.80 & 0.35 \\
$\mathrm{TiO}_{2}, \%$ & $\mathrm{NA}$ & $\mathrm{NA}$ & $\mathrm{NA}$ & 24 \\
$\mathrm{Na}_{2} \mathrm{O}, \%$ & 1.04 & 1.05 & 2.19 & 0.02 \\
$\mathrm{~K}_{2} \mathrm{O}, \%$ & 0.66 & 0.77 & 1.33 & 0.05 \\
$\mathrm{BaO} \%$ & 0.15 & 0.13 & $\mathrm{NA}$ \\
$\mathrm{Pb}, \mathrm{mg} / \mathrm{kg}$ & 0.15 & 391.84 & 72.00 & 110 \\
$\mathrm{Cu}, \mathrm{mg} / \mathrm{kg}$ & 420.00 & 179.93 & 135.00 & 60 \\
$\mathrm{Ni}, \mathrm{mg} / \mathrm{kg}$ & 172.00 & 169.93 & 678.78 & $\mathrm{NA}$ \\
$\mathrm{Zn}, \mathrm{mg} / \mathrm{kg}$ & 152.00 & 119.95 & 136.00 & 110 \\
$\mathrm{Co}, \mathrm{mg} / \mathrm{kg}$ & 116.00 & 95.96 & 140.00 & 40 \\
$\mathrm{Cr}, \mathrm{mg} / \mathrm{kg}$ & 104.00 & 91.96 & 233.48 & 160 \\
$\mathrm{Sr}, \mathrm{mg} / \mathrm{kg}$ & 64.00 & 43.98 & 149.11 & $\mathrm{NA}$ \\
$\mathrm{B}, \mathrm{mg} / \mathrm{kg}$ & 60.00 & $\mathrm{NA}$ & $\mathrm{NA}$ & 240 \\
$\mathrm{Mn}, \mathrm{mg} / \mathrm{kg}$ & $\mathrm{NA}$ & 284 & $\mathrm{NA}$ & 340 \\
$\mathrm{As}, \mathrm{mg} / \mathrm{kg}$ & 404 & $\mathrm{NA}$ & $\mathrm{NA}$ & 1.957 \\
$\mathrm{Hg}, \mathrm{mg} / \mathrm{kg}$ & $\mathrm{NA}$ & $\mathrm{NA}$ & 0.32 \\
$\mathrm{Mo}, \mathrm{mg} / \mathrm{kg}$ & $\mathrm{NA}$ & 81 & $\mathrm{NA}$ & $<20$ \\
\hline
\end{tabular}


Table 3

Chemical composition of desalinated seawater and desalinated seawater interacted with different types of fly ash and coal under batch experiments

\begin{tabular}{|c|c|c|c|c|c|c|c|c|c|}
\hline Source & $\mathrm{pH}$ & $\mathrm{Ca}$ & $\mathrm{Mg}$ & $\mathrm{Na}$ & $\mathrm{K}$ & $\mathrm{Cl}$ & $\mathrm{SO}_{4}$ & $\mathrm{~B}$ & $\begin{array}{l}\text { Boron } \\
\text { removal, \% }\end{array}$ \\
\hline Desalinized seawater (Elat) & 6.5 & 3.2 & 4.4 & 194 & 8.2 & 322 & 7 & 1.69 & - \\
\hline $\begin{array}{l}\text { Desalinized seawater after } \\
\text { interaction with Soma ash } \\
(24 \mathrm{~h}, \mathrm{~L} / \mathrm{S}=10)\end{array}$ & 12.4 & 1337 & 0.5 & 198 & 15.4 & 318 & - & 0.37 & 81 \\
\hline $\begin{array}{l}\text { Desalinized seawater after } \\
\text { interaction with South African } \\
\text { ash }(24 \mathrm{~h}, \mathrm{~L} / \mathrm{S}=10)\end{array}$ & 12.2 & 765 & 0.9 & 200 & 11.7 & 327 & - & 0.44 & 76 \\
\hline $\begin{array}{l}\text { Desalinized seawater after } \\
\text { interaction with Yenicoy ash } \\
(24 \mathrm{~h}, \mathrm{~L} / \mathrm{S}=10)\end{array}$ & 12.0 & 592 & 1.0 & 192 & 24.5 & 320 & - & 0.32 & 83 \\
\hline $\begin{array}{l}\text { Desalinized seawater after } \\
\text { interaction with Yatagan ash } \\
(24 \mathrm{~h}, \mathrm{~L} / \mathrm{S}=10)\end{array}$ & 12.0 & 592 & 0.9 & 203 & 25.0 & 328 & - & 0.39 & 79 \\
\hline Red Sea seawater & 8.2 & 418 & 1441 & 12,400 & 516 & 23,000 & 3080 & 5.3 & - \\
\hline $\begin{array}{l}\text { Seawater interacted with } \\
\text { Yenicoy coal }(24 \mathrm{~h}, \mathrm{~L} / \mathrm{S}=10)\end{array}$ & 7.4 & 1673 & 1202 & 12,533 & 410 & 22,410 & 3882 & 2.1 & 60 \\
\hline $\begin{array}{l}\text { Seawater interacted with } \\
\text { Yenicoy ash }(24 \mathrm{~h}, \mathrm{~L} / \mathrm{S}=10)\end{array}$ & 11.8 & 3400 & 0 & 13,050 & 480 & 22,580 & 2337 & 0.15 & 97 \\
\hline $\begin{array}{l}\text { Seawater interacted with South } \\
\text { Africa ash }(24 \mathrm{~h}, \mathrm{~L} / \mathrm{S}=10)\end{array}$ & 7.9 & 1763 & 813 & 13,650 & 473 & 24,610 & 3543 & 1.09 & 79 \\
\hline $\begin{array}{l}\text { Seawater interacted with Soma } \\
\text { ash }(16 \mathrm{~h}, \mathrm{~L} / \mathrm{S}=10)\end{array}$ & - & 3643 & 4.7 & 11,060 & 501 & - & - & 1.29 & 76 \\
\hline $\begin{array}{l}\text { Seawater interacted with } \\
\text { Yatagan ash }(16 \mathrm{~h}, \mathrm{~L} / \mathrm{S}=10)\end{array}$ & - & 1309 & 1203 & 11,200 & 545 & - & - & 1.31 & 75 \\
\hline
\end{tabular}

regular pressure. Use of gravitation alone to provide flow suffered from slow flow rates due to the very low permeability of the fly ash materials. Batch experiments were carried out in polyethylene flasks $(250 \mathrm{ml})$ at room temperature. The extracts from the two sets of experiments were filtered and analyzed for boron and other trace elements using ICP (Thermo Garell Ash, ICAP 61E Trace Analyzer). The precision of the boron analysis was carefully monitored by routine measurements of an external standard (i.e., seawater) in addition to internal calibration. The long-term precision of seawater replicates was $4 \%$. Chromium concentrations in solution were determined by ICP at the Israel Geological Survey with a detection limit of $20 \mu \mathrm{g} / \mathrm{l}$. Radioactivity measurements carried out at the Soreq Nuclear Center, Yavne, Israel.

\section{Results and discussion}

Various operational parameters were tested in order to determine the feasibility of using coal and fly ash materials for boron removal from aqueous solutions. These include time of reaction, material type, $\mathrm{pH}$, liquid/solid (L/S) ratio, salinity of the solution, and the pretrcatment/rcgeneration of the material after reaction with seawater.

\subsection{Column and batch experiments}

Column experiments were carried out to evaluate the effect of the material type on boron 
removal from seawater. The materials tested were Yenikoy coal, Yenikoy and South African fly ashes, zeolite, and boron-specific ion exchange resin (Amberlite). The results are presented in Fig. 1. The magnitude of boron removal varies from $60 \%$ to almost $98 \%$ for the coal and ash samples, while zeolite under the similar experimental conditions yielded only $20 \%$. The ability of coal and fly ash to remove boron is similar to that achieved by synthetic boron-specific ion exchange resin (Fig. 1). The column experiment results (Fig. 2) show that boron removal depends on the specific material (maximum removal by the coal), $\mathrm{pH}$ (maximum at a range of 8-10), and $\mathrm{L} / \mathrm{S}$ ratio $(<20)$. The salinity of the solution (i.e., natural seawater vs. double distilled water spiked with $B=5 \mathrm{mg} / \mathrm{l}$ ) affects the boron removal capacity in some materials.

The batch experiment results (Fig. 3) show that boron removal increases with increasing reaction time and reducing $\mathrm{L} / \mathrm{S}$ ratio, particularly for Yenikoy coal and South African ash samples. This tendency was not observed for Yenikoy ash. At a constant reaction time of $24 \mathrm{~h}$, increasing $\mathrm{L} / \mathrm{S}$ ratio decreases the boron removal, depending on the material type. This effect also seems less significant for Yenikoy ash sample (Fig, 4), which removes boron $(\sim 80 \%)$ even in a $\mathrm{L} / \mathrm{S}$ ratio of 80 , indicating a relatively high capacity for boron retention. In order to test the impact of $\mathrm{pH}$ conditions on boron removal, the $\mathrm{pH}$ of sea water was adjusted to $5,7,9$ and 10 under a fixed $\mathrm{L} / \mathrm{S}$ ratio and reaction time of $3 \mathrm{~h}$. The results show (Fig. 5) that boron removal by Yenikoy coal is not affected by the $\mathrm{pH}$ conditions. In contrast, boron removal by fly ash is strongly dependent on the $\mathrm{pH}$. A maximum boron retention occurs at about $\mathrm{pH} \sim 9$. Under low $\mathrm{pH}$ conditions the capacity of boron retention decreases and even boron is leached to the solution (Fig. 5).

\subsection{Regeneration}

We tested the removal capacity of the materials after several reaction cycles with seawater using $1 \%$ of glycerin solution in regeneration procedure.

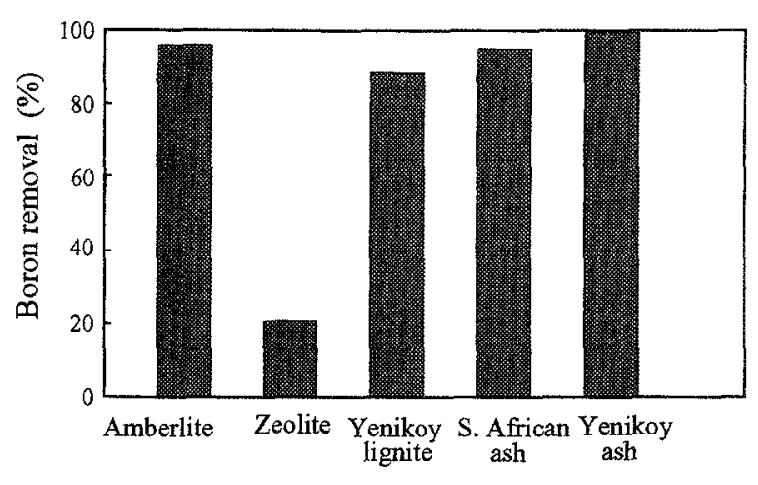

Fig. 1. Removal of boron by various materials $(5.3 \mathrm{mg} / 1$ boron solution; $\mathrm{pH}=9 ; \mathrm{S} / \mathrm{L}=1 / 10$ ) as preformed by column experiments.
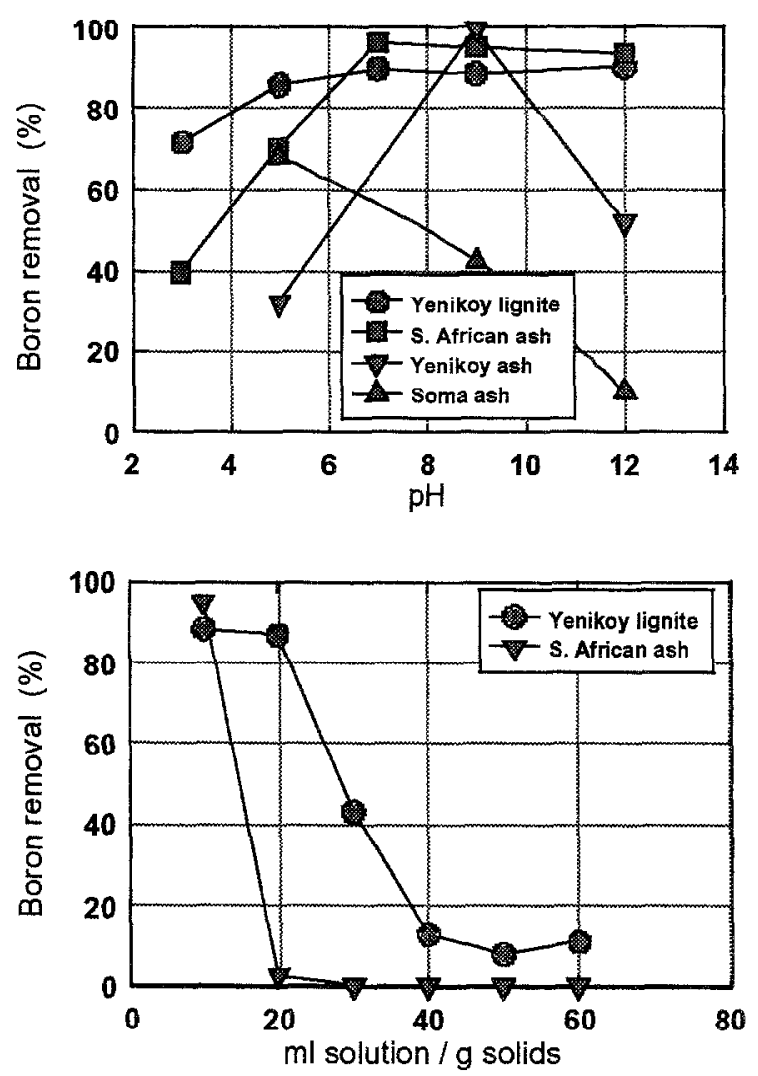

Fig. 2. Boron removal (\%) vs. $\mathrm{pH}$ and solution-to-solid ratio as preformed by column experiments. 

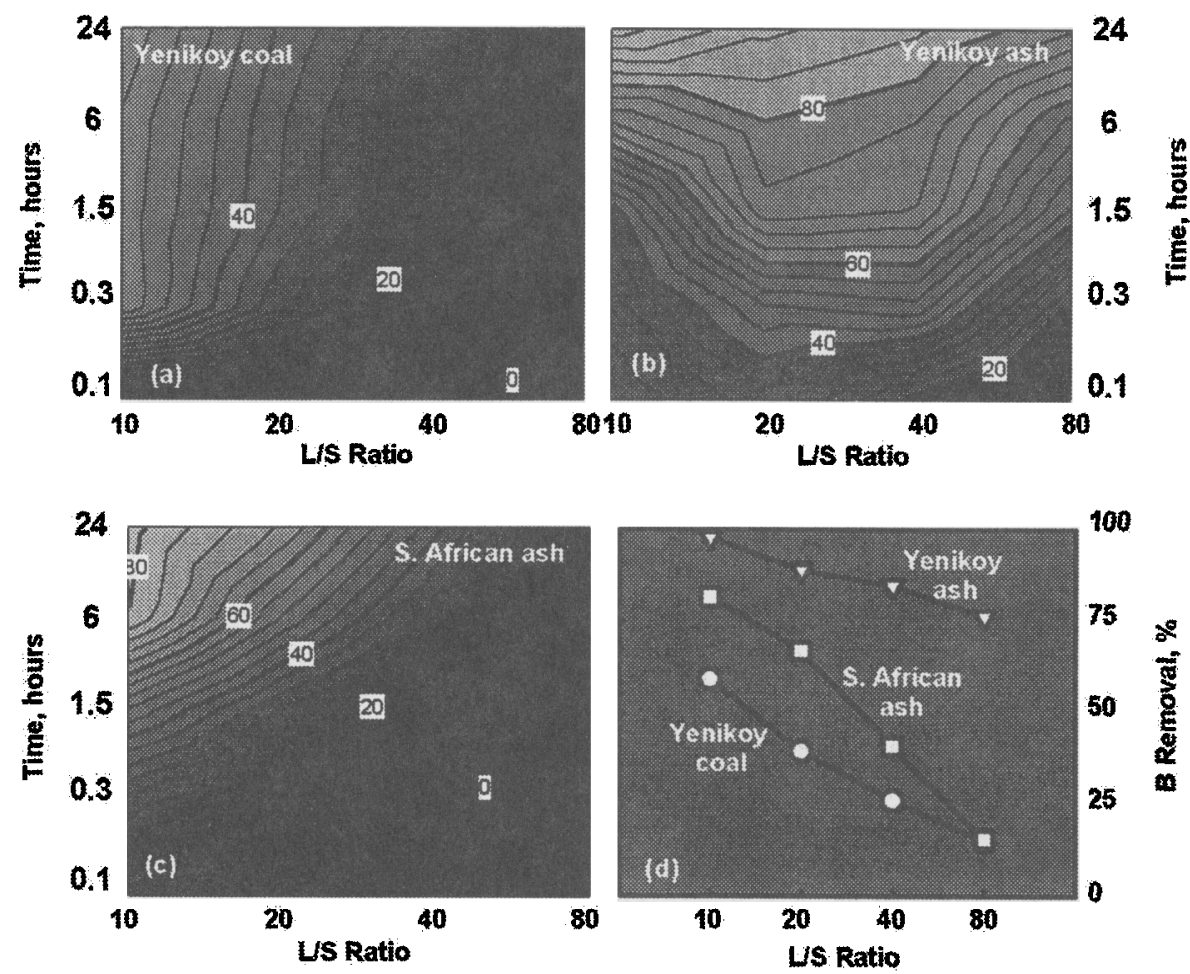

Fig. 3. A three-dimension presentation of boron removal (in \%, illustrated by colors) as a function of reaction time (h) and L/S ratio after interaction with three types of materials: Yenicoy coal (a), Yenicoy ash (b), and South Africa ash (c). The direct dependence of the boron removal on the L/S ratio is illustrated in graph (d).

Fig. 6 presents the detailed procedure for the regeneration process (defined as $\mathrm{R} 1$ ). The procedure has been applied 4 times (R1, R2, R3, R4) and the results are presented in Fig. 7. In the fly ash samples, the boron concentration in the residual solutions (Extract-D) increased with increasing number of regeneration steps. Hence the material's capacity to remove boron after several steps of reaction-and-regeneration is limited. However, the boron concentration in the residual solution that interacted with Yenikoy coal remained low (Fig. 7), indicating that this material is not loosing its capacity for boron retention after several cycles of reaction and regeneration with glycerin.

\subsection{Desalinated seawater}

We tested the boron removal from desalinated seawater by conducting batch experiments under fixed conditions ( $\mathrm{L} / \mathrm{S}$ ratio $=10,24 \mathrm{~h}$ of reaction). The results (Table 3 ) show a boron removal of about $80 \%$ that reduces the boron level close to the international drinking water standards of 0.3 $\mathrm{mg} / \mathrm{l}$. The interaction of fly ash with desalinated seawater results in a significant increase of $\mathrm{Ca}$, a slight increase in $\mathrm{K}$, and reduction of $\mathrm{Mg}$ contents. The concentrations of $\mathrm{Na}$ and $\mathrm{Cl}$ are not modified by interaction with fly ash.

\subsection{Chemical modification of residual seawater}

We measured the chemical composition of the residual water after interaction with different materials (Table 3 ) under different experimental conditions ( $\mathrm{pH}$, reaction time). As shown earlier, the boron removal factor depends on the $\mathrm{pH}$ (Figs. 2 and 5), reaction time (Fig. 3), and L/S ratio (Fig. 4). The results show that these factors also 


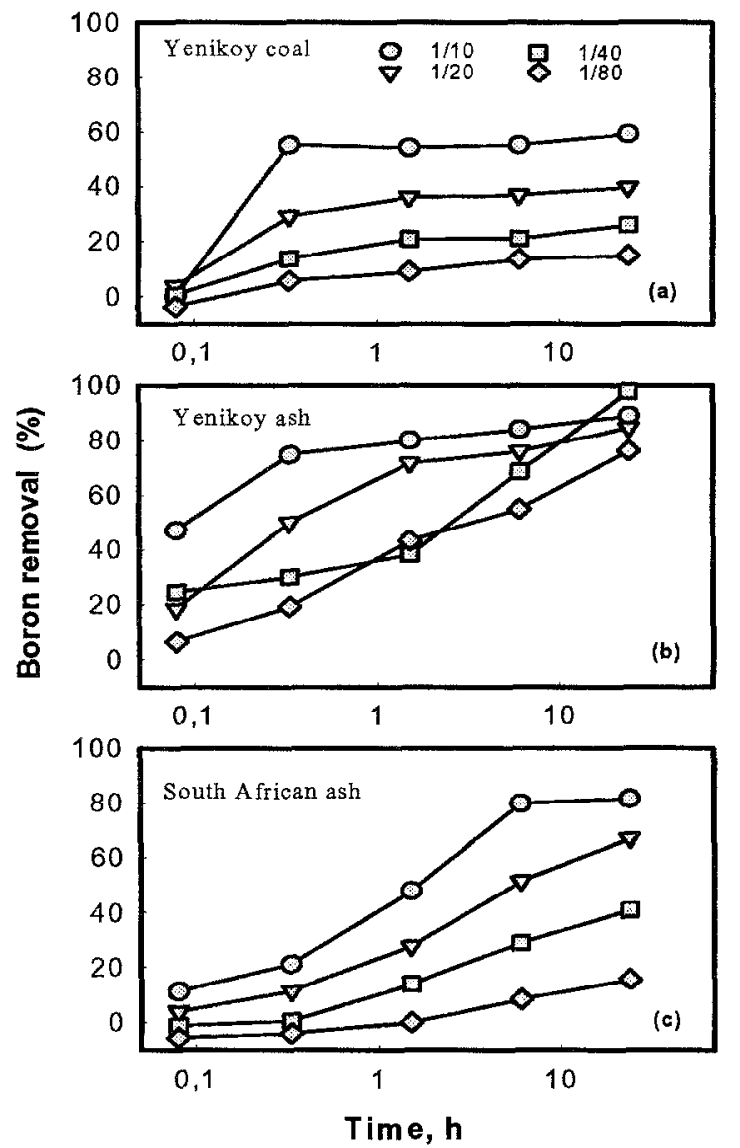

Fig. 4. Boron removal (\%) vs. reaction time in different $\mathrm{L} / \mathrm{S}$ ratios in Yenicoy coal (a), Yenicoy ash (b), and South Africa ash (c).

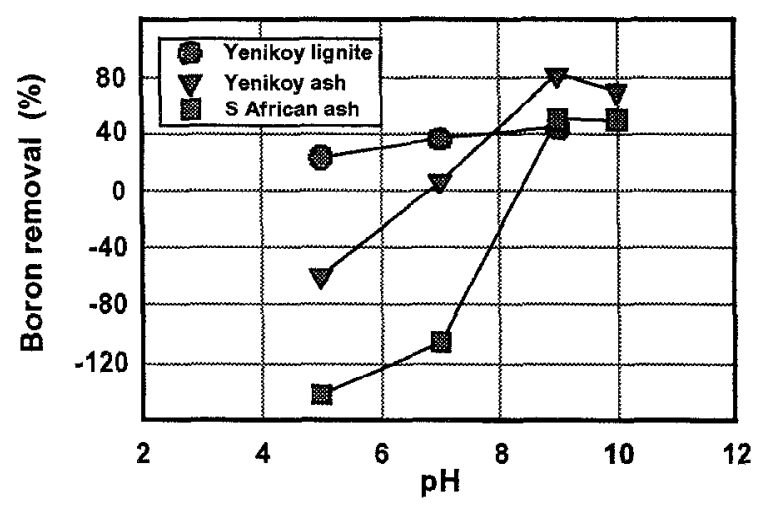

Fig. 5. Effect of $\mathrm{pH}$ on boron removal for different coal and ash materials $(S / L=1 / 20)$. Negative values indicate net release of $\mathrm{B}$ from the solid. play an important role over the chemical variation of the residual solution. The concentrations of $\mathrm{Cl}$ and $\mathrm{Ca}$ increase while $\mathrm{Mg}$ and $\mathrm{B}$ decease with decreasing $\mathrm{pH}$ (Fig. 8). In contrast, the variations of $\mathrm{Na}, \mathrm{K}$, and $\mathrm{SO}_{4}$ of seawater did not change upon interaction with fly ash and coal (Table 3). The removal of boron is strongly associated with relative $\mathrm{Ca}$ enrichment and $\mathrm{Mg}$ depletion in the residual solution (Fig. 9). In sum, as a result of interaction with coal and fly ash seawater becomes slightly more saline (about $10 \%$ ), significantly enriched in $\mathrm{Ca}$, and depleted in $\mathrm{Mg}$ and $\mathrm{B}$. It is interesting to note that the three different materials have similar effect on the chemical composition of the residual seawater. The high $\mathrm{Ca}$ release particularly in the Yenikoy ash (Fig. 9) is related to the large $\mathrm{CaO}$ content of this material $(38.2 \%)$ relative to South Africa ash (8.3\%).

In order to evaluate the relationship between the amount of ions that are retained $(\mathrm{B}, \mathrm{Mg})$ and released $(\mathrm{Ca})$ from seawater after interaction with coal and fly ash, we measured the concentration of these elements in leachates extracted from the original (i.e., before the reaction) and residual fly ash. We performed a simple experiment $(24 \mathrm{~h}$, $\mathrm{L} / \mathrm{S}=10$ ) that is consistent with maximum boron removal and measured the concentration of these elements in seawater, residual seawater (after reaction), and leachates (with DDW and I M nitric acid) extracted from the original and residual fly ash (Table 4). Our mass-balance calculations indicate that the amount of $\mathrm{Ca}, \mathrm{Mg}$, and $\mathrm{B}$ in seawater plus acid leachate from untreated fly ash is balanced (within a reaction error of less than $2 \%$ ) with the sum of the residual solution (after the reaction) plus the acid leachate of residual fly ash. Water leaching of the fly ash failed to extract appropriate concentrations to balance between input (seawater + fly ash) and output (residual seawater + residual fly ash).

\subsection{Potential hazard side effects}

Leaching of fly ash may cause formation of environmental hazards in the leachates such as 


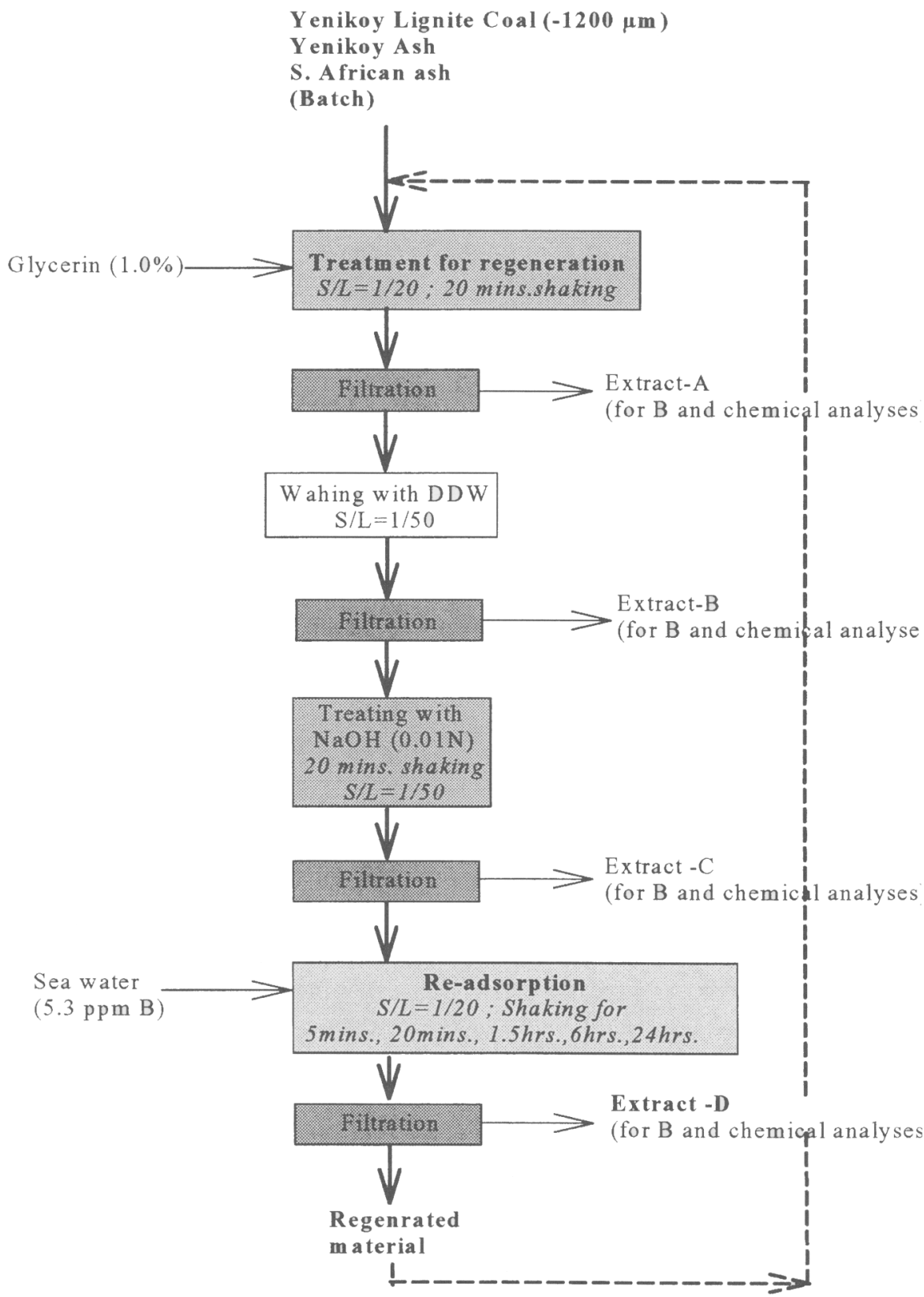

Fig. 6. The flow sheet presentation of one regeneration process (R1) as part of reacting and washing fly ash and coal materials. 


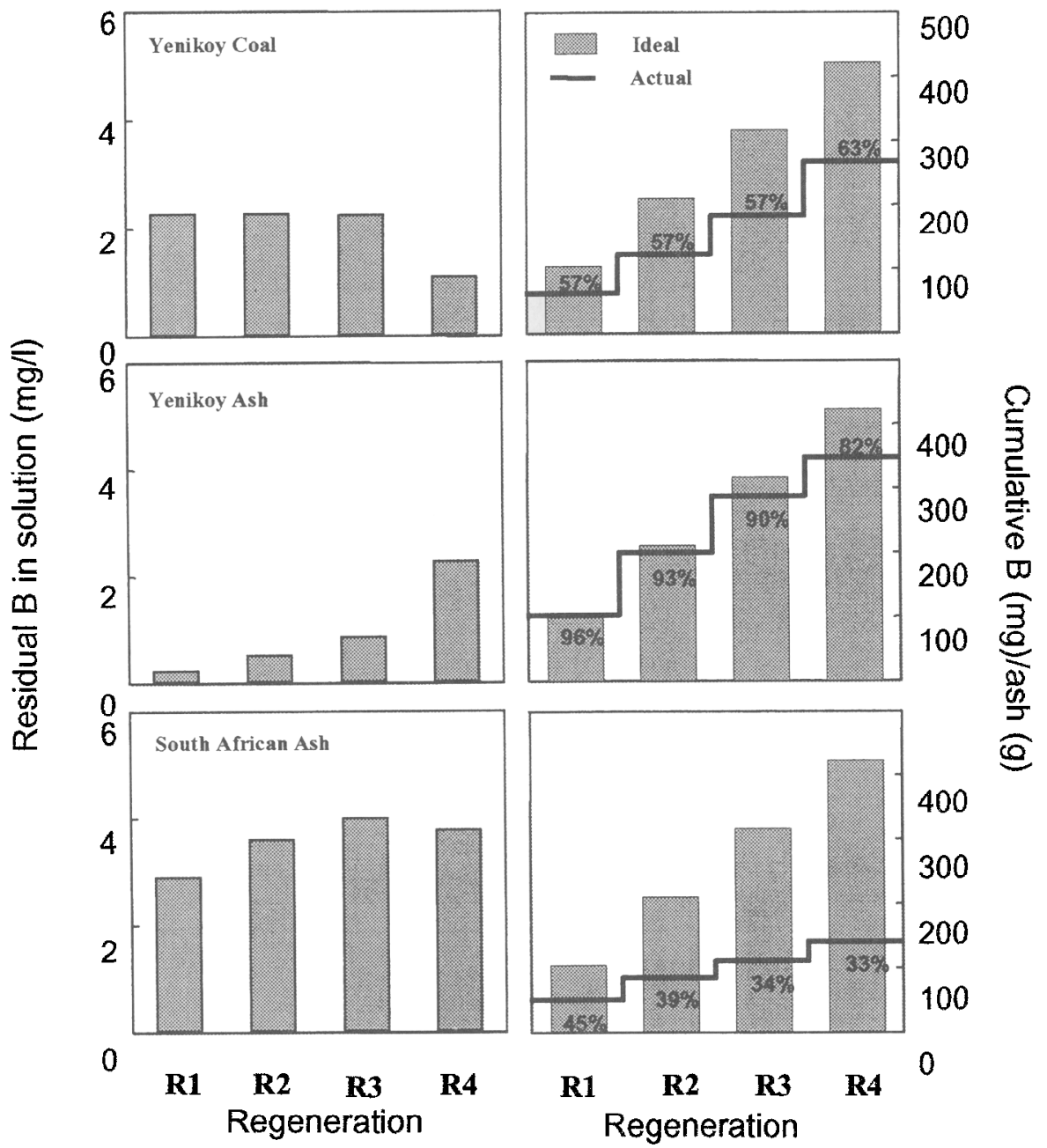

Fig. 7. Boron content in residual solutions (left hand side columns) and cumulative boron (mg per $g$ ash) (right hand side columns) after several cycles of interaction and regeneration with Yenicoy coal (a), Yenicoy ash (b), and South Africa ash (c). The bars in the right-hand side columns correspond to the ideal cumulative of $\mathrm{B}$ (in $\mathrm{mg}$ ) that would be removed by $1 \mathrm{~g}$ of ash under $100 \%$ removal after each run. Each time $20 \mathrm{ml}$ of seawater interacted with $1 \mathrm{~g}$ of solid material. Thus the accumulated boron is $0.106,0.212,0.318$ and $0.424 \mathrm{mg} \mathrm{B}$ per gram of ash, respectively for four steps of reaction and regeneration. The step-wise lines correspond to the actual accumulation of $B$ that was removed per gram of ash after each run. The cumulative percentage of actual removal out of theoretical boron accumulation is shown under the line for each run. 

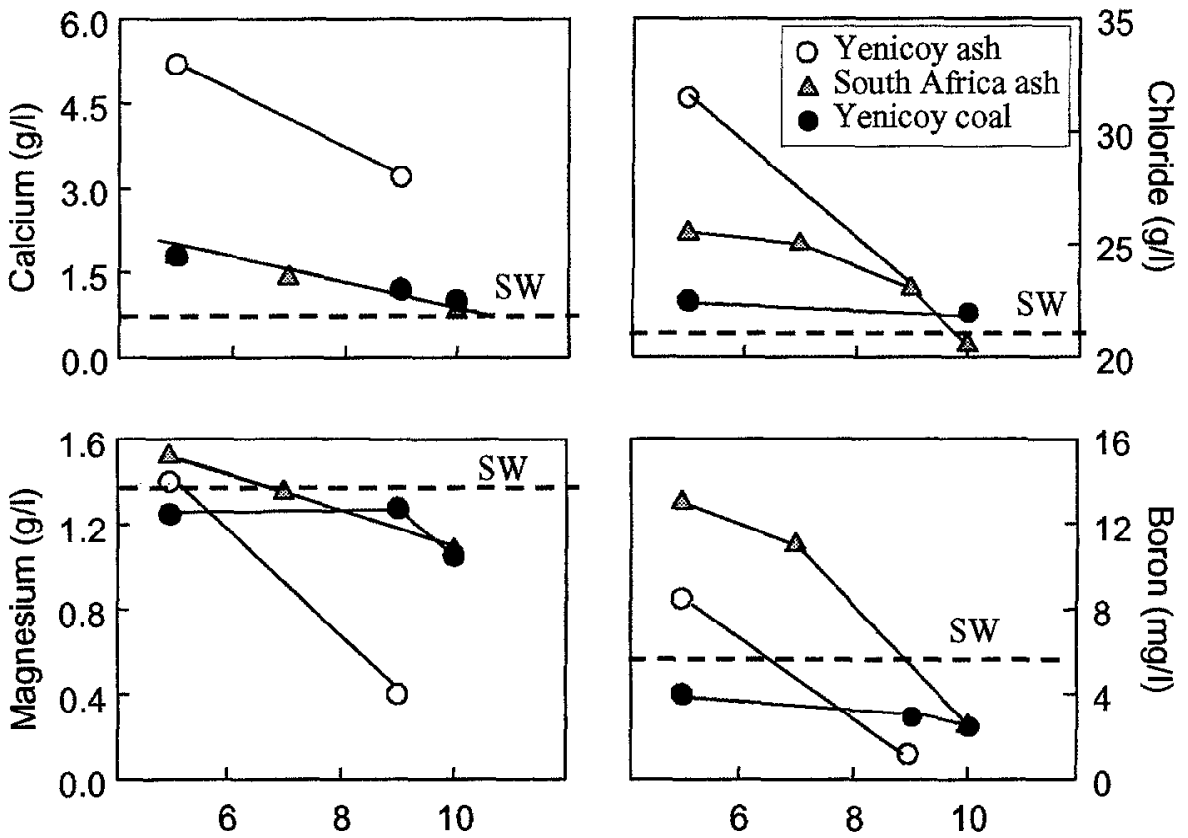

$\mathrm{pH}$

Fig. 8. Variations of $\mathrm{Ca}, \mathrm{Mg}, \mathrm{Cl}$, and $\mathrm{B}$ as a function of $\mathrm{pH}$ in residual seawater interacted with Yenicoy coal, Yenicoy ash, and South Afica ash $(\mathrm{L} / \mathrm{S}$ ratio $=20)$.
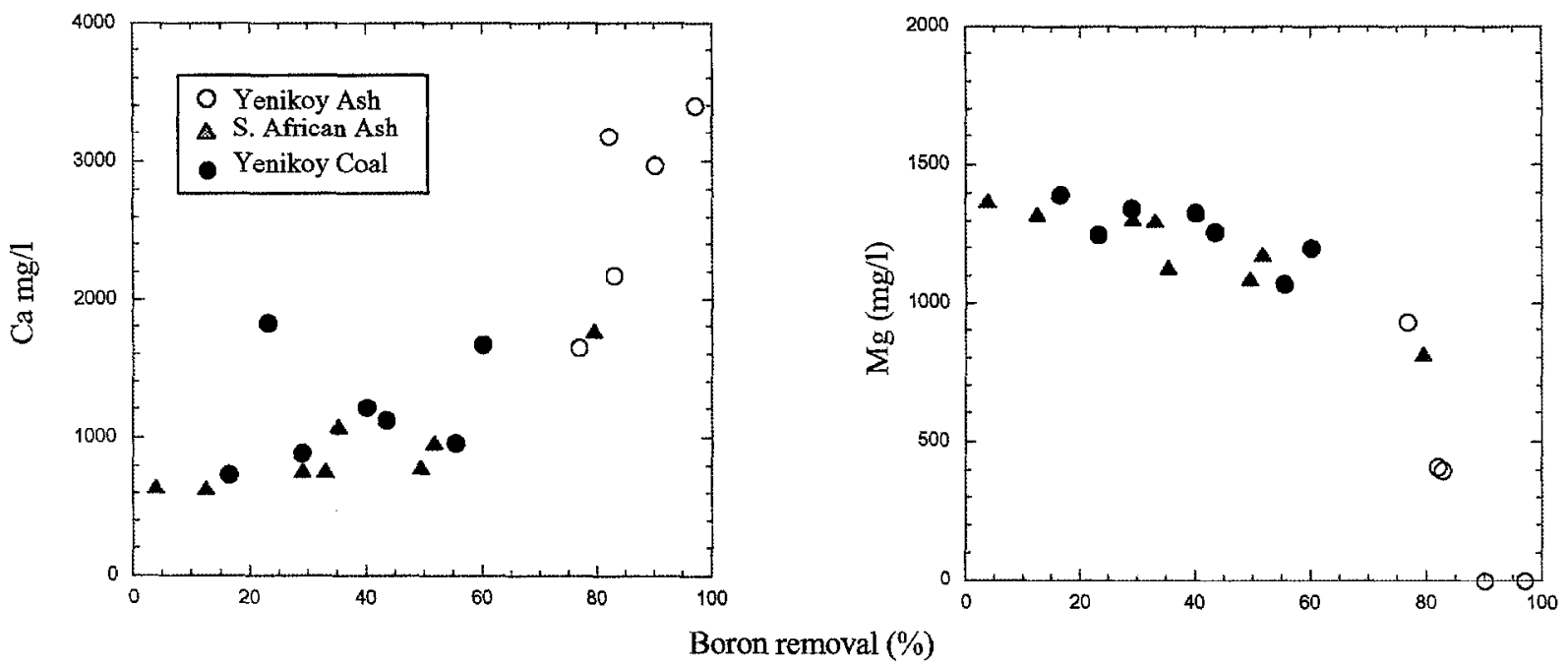

Fig. 9. The concentrations of $\mathrm{Ca}$ and $\mathrm{Mg}$ vs. boron removal (\%) as measured in residual seawater interacted with different types of materials. 
Table 4

Concentrations of solutes in solution and in leachates extracted from fly ash by acid and water (in mg/). Mass-balance between "input" and "output" shows an equal amount for acid extraction but relative deficiency for water extraction

Acid extractions

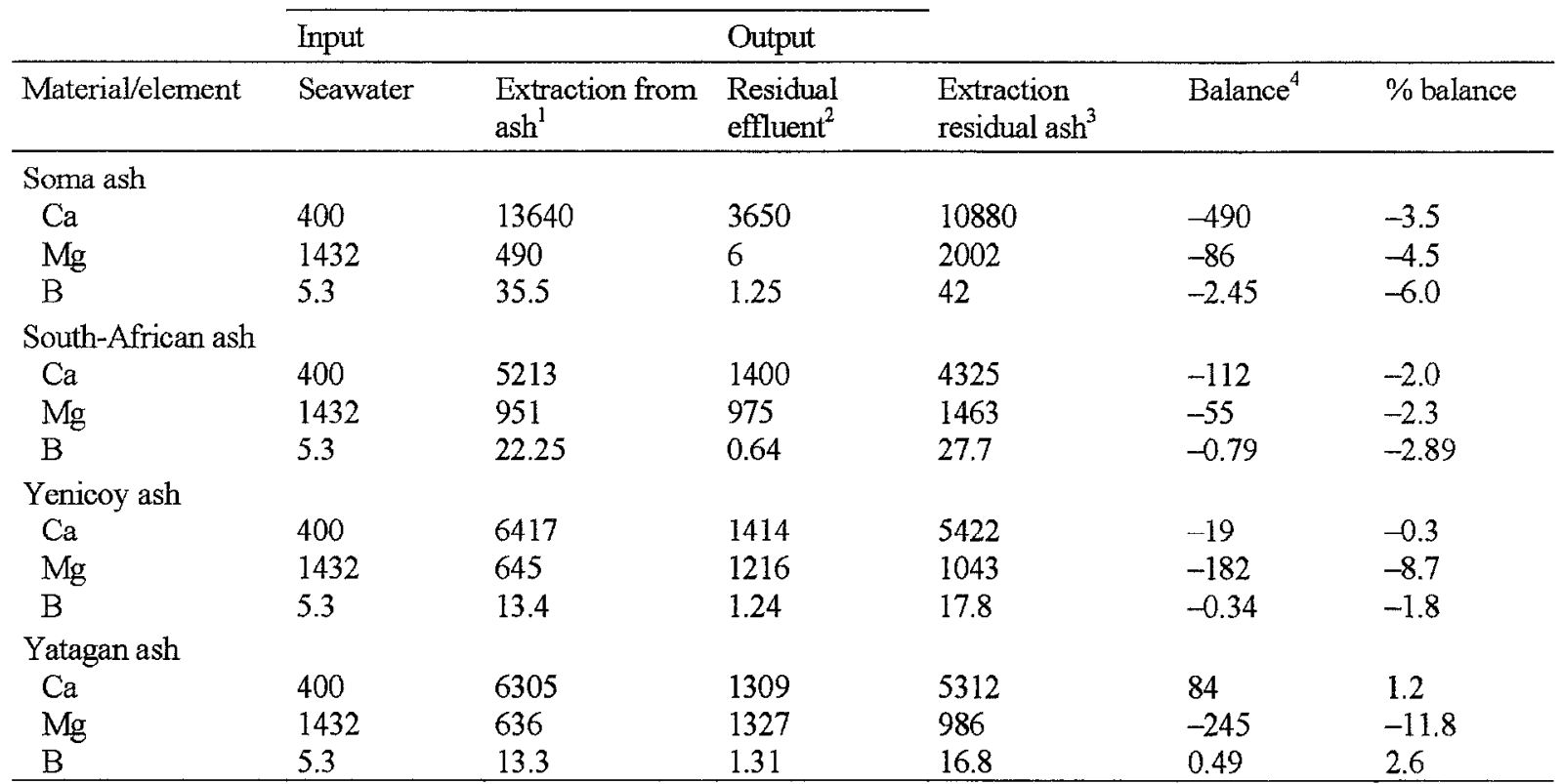

Water extractions

\begin{tabular}{|c|c|c|c|c|c|c|}
\hline & \multirow{2}{*}{\multicolumn{2}{|c|}{ Input }} & \multirow{2}{*}{\multicolumn{2}{|c|}{ Output }} & \multirow{3}{*}{ Balance $^{4}$} & \multirow[b]{3}{*}{$\%$ balance } \\
\hline & & & & & & \\
\hline Material/element & Seawater & $\begin{array}{l}\text { Extraction from } \\
\operatorname{ash}^{1}\end{array}$ & $\begin{array}{l}\text { Residual } \\
\text { effluent }^{2}\end{array}$ & $\begin{array}{l}\text { Extraction } \\
\text { residual ash }\end{array}$ & & \\
\hline \multicolumn{7}{|l|}{ Soma ash } \\
\hline $\mathrm{Ca}$ & 400 & 1262 & 3650 & 1541 & -3529 & -212 \\
\hline $\mathrm{Mg}$ & 1432 & 1 & 6 & 1.5 & 1425 & 99 \\
\hline$B$ & 5.3 & 0.29 & 1.25 & 0.2 & 4.14 & 74 \\
\hline \multicolumn{7}{|l|}{ South-African ash } \\
\hline $\mathrm{Ca}$ & 400 & 627 & 1400 & 294 & -667 & -65 \\
\hline $\mathrm{Mg}$ & 1432 & 0.9 & 975 & 3.9 & 164 & 11 \\
\hline B & 5.3 & 0.06 & 0.64 & 3.2 & 1.52 & 28 \\
\hline \multicolumn{7}{|l|}{ Yenicoy ash } \\
\hline $\mathrm{Ca}$ & 400 & 519 & 1414 & 356 & -851 & -93 \\
\hline $\mathrm{Mg}$ & 1432 & 0.04 & 1216 & 2.9 & 213 & 15 \\
\hline$B$ & 5.3 & 0.26 & 1.24 & 2.1 & 2.2 & 40 \\
\hline \multicolumn{7}{|l|}{ Yatagan ash } \\
\hline $\mathrm{Ca}$ & 400 & 492 & 1309 & 346 & -763 & -86 \\
\hline $\mathrm{Mg}$ & 1432 & 0.1 & 1327 & 2.7 & 102 & 7 \\
\hline $\mathrm{B}$ & 5.3 & 0.29 & 1.31 & 1.9 & 2.4 & 43 \\
\hline
\end{tabular}

${ }^{1}$ Extraction from original ash without any treatment

${ }^{2}$ Residual seawater efluent after $16-24 \mathrm{~h}$ of interaction with ash, $\mathrm{S} / \mathrm{L}$ ratio $=10$

${ }^{3}$ Extraction from residual ash after interaction with seawater

${ }^{4}$ Balance between input and output (i.e., total input-total output) 
Table 5

Concentration of gamma-emission radionuclide elements in residual seawater that interacted (1/10 ratio) for $24 \mathrm{~h}$ with different types of coal and fly ash samples. Results are reported in Bequerels/L. Values in brackets refer to MDA values which are the minimum detectable activity (in $95 \%$ confidence). Radionuclide presence in samples is only in cases where the result value is higher than the uncertainty $( \pm$ ) and MDA values. Measurements were carried out at Soreq Nuclear Research Center, Yavne, Israel.

\begin{tabular}{llll}
\hline Sample & ${ }^{226} \mathrm{Ra}$ & ${ }^{232} \mathrm{Th}$ & ${ }^{40} \mathrm{~K}$ \\
\hline Yenicoy ash & $0.58 \pm 0.32(0.75)$ & $<0.07(0.95)$ & $18.46 \pm 4.52(5.69)$ \\
Tenicoy coal & $1.44 \pm 0.3(0.62)$ & $\varangle 0.06(0.50)$ & $14.93 \pm 3.64(4.18)$ \\
South Africa ash & $0.25 \pm 0.42(0.55)$ & $<0.05(0.46)$ & $15.30 \pm 3.7(4.40)$ \\
\hline
\end{tabular}

radionuclides and heavy metals [26]. In particular, the Turkish fly ashes that were used in our experiments are known to have relatively high radioactivity [27]. We tested the radioactivity of the residual seawater after being interacted for $24 \mathrm{~h}$ with Yenikoy coal and two ash samples (Yenikoy and South Africa). Our results (Table 5) show that the level of ${ }^{226} \mathrm{Ra}$ and ${ }^{232} \mathrm{Th}$ radio-nuclides in the leachates are very low and only in one case (Yenikoy coal) we were able to find traceable ${ }^{226} \mathrm{Ra}$ above the detection limit of the gamma-emission technique. ${ }^{40} \mathrm{~K}$ activity was found in all leachate samples but has no health hazards. It seems that hazardous radioactive nuclides are not leached upon interaction with seawater, although further study is required to test all aspects of radioactivity concentration in leachate extraction.

Leaching of fly ash can potentially result in extraction of many environmental pollutants (e.g., sulfur, chromium, arsenic, selenium, lead, cadmium, cupper, nickel, and zinc [26]). Here we tested the potential $\mathrm{Cr}$ contamination in two types of solutions that interacted with fly ash: desalinated seawater and raw seawater. The results are presented in Table 6 . We observed a wide range of $\mathrm{Cr}$ concentration, between 135-490 $\mu \mathrm{g} / \mathrm{l}$. The results indicate that the amount of chromium leached from fly ash depends on the type of the material and the salinity, as previously demonstrated $[22,26]$. Raw seawater interacted with fly ash resulted in higher (10-20\%) concentrations of leached chromium. Although leaching of chromium to the solution may require further treatment, we
Table 6

Concentrations of chromium in residual desalinated seawater and seawater after interaction (1/10 ratio) for $24 \mathrm{~h}$ with different types of coal and fly ash samples. Results are reported in $\mu g / 1$ and are the average of duplicate leaching experiments carried out for each of the samples.

\begin{tabular}{lll}
\hline Water & Material & $\mathrm{Cr}$ \\
\hline Desalinated seawater & Yatagan ash & 168 \\
Desalinated seawater & Yenicoy ash & 168 \\
Desalinated seawater & Soma ash & 135 \\
Desalinated seawater & South African ash & 317 \\
Desalinated seawater & (blank) & $<20$ \\
Seawater & Yatagan ash & 222 \\
Seawater & Yenicoy ash & 230 \\
Seawater & Soma ash & 188 \\
Seawater & South African ash & 490 \\
Seawater & (blank) & $<20$ \\
\hline
\end{tabular}

expect that the chromium level will be significantly reduced after $\mathrm{RO}$ desalination, and thus the desalinated water would become low in both boron and chromium. The relatively high chromium in the source water would require however careful management of the residual brines and avoiding discharge to the environment.

\subsection{Mechanism of boron retention by fly ash}

During combustion of coal most of the boron that is released due to decomposition of the organic matter is retained into the silicate (mullite), iron oxides and calcium oxides in the new forming fly ash [28]. Consequently, boron in fly ash exists 
in two phases: the leachable and mineralogical bound. It has been shown that under low $\mathrm{pH}$ conditions a large fraction of boron is leached from fly ash [20-25]. Our results also confirm that the $\mathrm{pH}$ has an important role on the distribution between fly ash and liquid phase (Fig. 5). The pH has also important affect on the overall chemical composition. Under low $\mathrm{pH}$ condition $\mathrm{Ca}$ and $\mathrm{Cl}$ are leached to the residual solution whereas $\mathrm{Mg}$ content in the residual solution is identical to that of the original seawater (Fig. 8).

In previous studies $[20-25]$ the leaching of boron was made by mainly DDW so the solutes that predominate the effluent composition were derived from the fly ash itself. In this study reactions were made with seawater that imposes its own composition on the residual effluent. In order to account the seawater impact we preformed a detailed mass-balance of solutes that considers both the solution and leachate from fly ash. Our results (Table 4) show that balance is achieved only by acid extraction from the fly ash whereas water leaching does not extract sufficient amount of solutes to balance the amount of $\mathrm{Ca}, \mathrm{Mg}$, and $B$. The lack of balance suggests that these elements are not only adsorbed onto the surface of fly ash as previously argued [25]. For example, during the adsorption of boron with clay minerals the adsorption capacity depends on the ratio between the dissolved and adsorbed species [29-33]. Thus, one would expect that DDW leaching would extract the adsorbed boron. The fact that only acid extraction releases all of the boron suggests that dissolution process also takes place.

The balance of the ions and the inverse relationships between $\mathrm{Mg}$ depletion and $\mathrm{Ca}$ enrichment (Fig. 9) suggest that the reaction of Ca-rich fly ash with $\mathrm{Mg}$-rich seawater causes coprecipitation of $\mathrm{Mg}$-hydroxides. Conversely, the co-precipitation of $\mathrm{Mg}$-hydroxides triggers dissolution of $\mathrm{Ca}$-oxides that releases $\mathrm{Ca}$ to the solution. Moreover, the $\mathrm{Ca} / \mathrm{Mg}$ ratios in the acid leachates (Table 4) are similar to the $\mathrm{CaO} / \mathrm{MgO}$ ratios in the bulk ash samples (Table 2), thus indicating that the main mechanism that controls seawater chemistry upon interaction with fly ash is dissolution and precipitation of $\mathrm{Ca}$ - and $\mathrm{Mg}$-oxides, respectively.

The relationships of boron removal with $\mathrm{Mg}$ depletion (Fig. 9) indicate an uptake of boron by $\mathrm{Mg}$-hydroxides. The uptake of boron by hydroxyoxides of $\mathrm{Al}, \mathrm{Fe}$ and $\mathrm{Mg}$ was studied extensively $[30,34]$. It was shown that boron uptake by hydroxy-Al is considerably larger (by a factor of 7) than adsorption onto clay mineral (e.g., Camontmorillonite) under the same conditions [32, 34]. Moreover, it has been shown that $\mathrm{Mg}$ hydroxide has an appreciable capacity for boron retention [35]. It was suggested that the hydroxyl groups in the coordination sphere act as bridging ligands between the adsorbed boron (as $\mathrm{B}(\mathrm{OH})_{4}^{-}$) and the surface of $\mathrm{Fe}$ and $\mathrm{Al}$ oxides [25], which explains the dependence of boron removal on $\mathrm{pH}$ conditions and hence boron coordination in the solution.

Magnesium oxides precipitated from seawater is one of the most important processes of production of high-temperature resistant ceramics [36]. The procedure includes reaction of seawater with dolomite lime and precipitation of magnesium hydroxide. During this process boron is co-precipitated and accumulated in magnesium hydroxide $(0.19 \%)$ [36]. We suggest that a similar process takes place during interaction of seawater with coal and fly ash. The combination of release of oxides from fly ash, the high-pH conditions, and the supply of Mg from seawater results in precipitation of magnesium hydroxide.

The formation of ion-pair borate species during interaction of seawater with fly ash may explain why boron is co-precipitated with magnesium hydroxide. During evaporation of sea water boron is precipitated mainly in the form of magnesium borate that is converted to boracite mineral $\left(\mathrm{Mg}_{3} \mathrm{Cl}\left(\mathrm{B}_{7} \mathrm{O}_{13}\right)[37,38]\right.$. Evaporated sea water at the stages where magnesium sulfate and potash salts are deposited is close to saturation with respect to various $\mathrm{Mg}$-borate minerals (ascharite, 


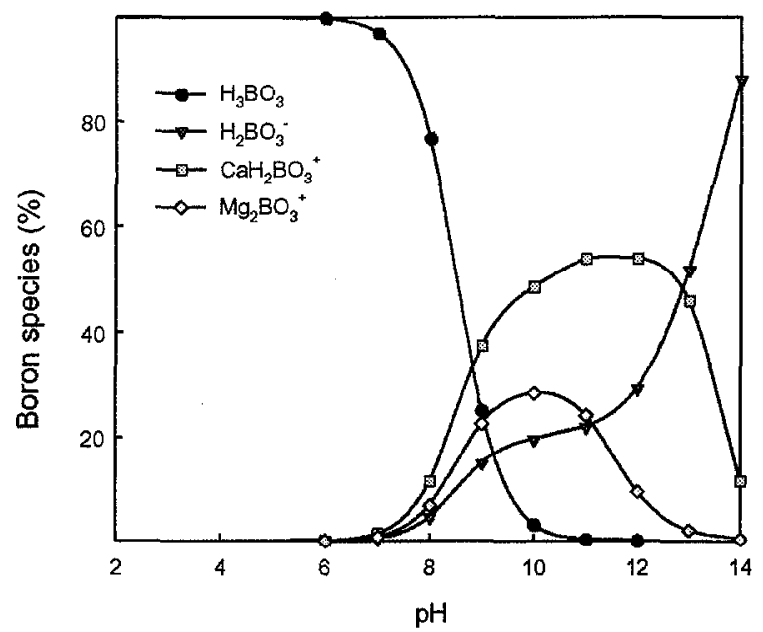

Fig. 10. Calculation of the distribution of boron species in a residual seawater solution that has been interacted with fly ash $(\mathrm{Ca}=1000 \mathrm{mg} / \mathrm{l}, \mathrm{Mg}=1000 \mathrm{mg} / \mathrm{l}, \mathrm{B}=$ $5.3 \mathrm{mg} / 1$; Table 3). Note the formation of $\mathrm{Ca}$ - and $\mathrm{Mg}$ borate ion pairs at high $\mathrm{pH}$ conditions.

kaliborite, and pinnoite) [38]. The formation of $\mathrm{Mg}$-borate ion pair $\left[\mathrm{MgB}(\mathrm{OH})_{4}^{+}\right]$and co-precipitation with evaporate salts is the mechanism that was proposed for boron removal from seawater, as evidenced also by boron isotopic composition [39]. Our calculations show that the $\mathrm{Mg}$ - and $\mathrm{Ca}-$ borate ion pair composed of about $80 \%$ of the total dissolved boron in a solution that has been interacted with fly ash $(\mathrm{Ca}=1000 \mathrm{mg} / \mathrm{l}, \mathrm{Mg}=$ $1000 \mathrm{mg} / \mathrm{l}, \mathrm{B}=5.3 \mathrm{mg} / \mathrm{l}$; Table 3 ) at $\mathrm{pH}$ value of $\sim 11$ (Fig. 10). Consequently, the formation of positive borate-ion pair may cause coordinative bonds with the negatively charged magnesium hydroxide surfaces. In sum, we suggest that the interaction with $\mathrm{Mg}$-rich seawater enhances magnesium hydroxide precipitation. The large tendency of magnesium hydroxide to retain boron results in co-precipitation of boron and its removal from the solution.

\section{Conclusions}

Our experiments show that a considerable amount of boron (>90\%) can be removed from seawater and desalinated seawater due to interaction with fly ash and coal under suitable conditions of high $\mathrm{pH}(>9)$, low $\mathrm{L} / \mathrm{S}(<20)$, and reaction time $(>6 \mathrm{~h})$. The combination of boron removal by fly ash ( $80 \%$ removal) and a single stage RO desalination ( $65 \%$ ) would reduce the boron content to $<0.4 \mathrm{mg} / 1$ in the residual water, which is sufficient to resolve the boron problem in desalination plant. However, the increase of calcium (1000-2000 mg/l), chloride ( $10 \%)$, and $\mathrm{pH}$ would require additional pretreatment measures before applying for RO desalination. In addition, leaching of chromium from fly ash requires special management for the brines that would be generated after $\mathrm{RO}$ desalination. The removal of boron occurs also for desalinated seawater after $\mathrm{RO}$ desalination, but significant $\mathrm{Ca}$ leaching increases the salt content of the treated water. Our regeneration experiments showed that fly ash, which is an abundant and cheap material could be used only for several reaction cycles and thus industrial operation would require continuous transport of both the solid and liquid to the reactor. The coal experiment yielded, however, much more promising results for continuous treatment and regeneration using $1 \%$ glycerin, enabling multiple treatment cycles of coal material.

This study demonstrates that boron removal is controlled by the material type and operational conditions $(\mathrm{pH}, \mathrm{S} / \mathrm{L}$ ratio, $\mathrm{pH})$. Some materials can be regenerated (coal), while others have high boron retention capacity (e.g., Yenikoy ash) with sufficient boron removal at a high $\mathrm{L} / \mathrm{S}$ ratio (80). The applicability of the new method therefore depends on the type and availability of the coal and fly ash.

\section{Acknowledgement}

The present study was partly co-financed by the European Union in the framework of the 5th European research project BOREMED (contract EVK1-CT-2000-00046). We also thank Gustavo Haquin from Soreq Nuclear Center (Yavne) for radioactivity measurements. 


\section{References}

[1] World Health Organization, Guidelines for Drinking Water Quality, 2nd ed., 1993, Geneva.

[2] E. Mastromatteo and F. Sullivan, Summary: International Symposium on the Health Effects of Boron and Its Compounds. Environ. Health Perspectives, 102 (1994) 139-141.

[3] M. Matsumoto, K. Kondo, M.S. Hirata, T. Kokubu, $T$. Hano and T. Takada, Recovery of boric acid from wastewater by solvent extraction, Separ. Sci. Technol., 32(5) (1997) 983-991.

[4] F.J. Murray, Issues in boron risk assessment: pivotal study, uncertainly factors and ADIs, J. Trace Elemen. Experim. Med., 9 (1996) 231-243.

[5] A. Vengosh, K.G. Heumann, S. Juraske and R. Kasher, Boron isotope application for tracing sources of contamination in groundwater, Envi. Sci. Technol., 43 (1994) 231-237.

[6] Y. Magara, T. Aizawa, S. Kunikane, M. Itoh, M. Kohki, M. Kawasaki and H. Taeut, The behavior of inorganic constituents and disinfection by products in reverse osmosis water desalination process, Water Sci. Technol., 34 (1996) 141-148.

[7] Y. Magara, A. Tabata, M. Kohki, M. Kawasaki and M. Hirose, Development of boron reduction system for sea water desalination, Desalination, 118 (1998) 25-34.

[8] N. Nadav, Boron removal from seawater reverse osmosis permeate utilizing selective ion exchange resin, Desalination, 124 (1999) 131-135.

[9] D. Prats, M.F. Chillon-Arias and M. RodriguezPastor, Analysis of the influence of $\mathrm{pH}$ and pressure on the elimination of boron in reverse osmosis, Desalination, 128 (2000) 269-273.

[10] M.R. Pastor, A.F. Ruiz, M.F. Chillion and D.P. Rico, Influence of $\mathrm{pH}$ in the elimination of boron by means of reverse osmosis, Desalination, 140 (2001) 145152.

[11] International Atomic Energy Agency, Processing of nuclear power plant waste streams containing boric acid, IAEA-TECHDOC-911, 1996.

[12] Rohm and Haas, 1997, Product Data Sheet PDS 0576A.

[13] W.R. Lyman and A.F. Preuss, Boron adsorption resin and process for removing boron compounds from fluids, US Patent No. 2813838, 1957.

[14] R. Kunin and A.F. Preuss, Characterization of boronspecific ion exchange resin, Induds. Eng. Chem.: Prod., Res. Develop., 3 (1964) 304-306.
[15] M.-O. Simonnot, C. Castel, M. Nicola, C. Rosin, M. Sardin and H. Jauffret, Boron removal from drinking water with a boron selective resin: is the treatment really selective?, Water Res., 34 (2000) 109-116.

[16] O. Okay, H. Guçlu, E. Soner and T.Balkas, Boron pollution in the Simav River, Turkey and various methods of boron removal, Water Res., 19 (1985) $857-862$.

[17] O. Recepoglu and Ü. Beker, A preliminary study of boron removal from Kizildere Turkey geothermal waste water, Geothermics, 20 (1991) 83-89.

[18] M. Badruk, N. Kabay, M. Demircioulu, H. Mordouan and U. Ipekoglu, Removal of boron from wastewater of geothermal power plant by selective ion-exchange resin. I. Batch sorption-elution studies, Sep. Sci. Technol., 34 (1999) 2553-2569.

[19] L. Melnik, O. Vysotskaja and B. Kornilovich, Boron behavior during desalination of sea and underground water by electrodialysis, Desalination, 124 (1999) 125-130.

[20] D.R. Jones, In Environmental Aspects of Trace Elements in Coal, Kluwer Academic Publ., Dordrecht, 1995, pp. 221-255.

[21] Y. Nathan, M. Dovrackek, I. Pelly and U. Mimran, Characterization of coal fly ash from Israel, Fuel, 78 (1999) 205-213.

[22] S. Sheps-Pelleg and H. Cohen, Workshop on Novel Products from Combustion Residues, Morella, Spain, 2001.

[23] J.A. Cox, GL. Lundquist, A. Przyjazny and C.D. Schmulbach, Lcaching of boron from coal ash, Env. Sci. Technol., 12 (1978) 722-723.

[24] W.D. James, C.C. Graham, M.D. Glascock and A.S.G. Hanna, Water-leachable boron from coal ashes, Env. Sci. Technol., 16 (1982) 195-197.

[25] J.F. Hollis, R. Keren and M. Gal, Boron release and sorption by fly ash as affected by $\mathrm{pH}$ and particle size, J. Environ. Qual., 17 (1988) 181-184.

[26] D.J. Swaine and F. Goodarzi, Environmental Aspects of Trace Elements in Coal, Kluwer Academic Publ., 1995. $312 \mathrm{p}$.

[27] G.A. Aycik and A. Ecran, Radioactivity measurements of coal and ashes from coal-fired power plants in the southwestern part of Turkey, J. Environ. Radioactivity, 35 (1997) 23-35.

[28] R.B. Clark, S.K. Zeto, K.D. Ritchey and V.C. Baligar, Boron accumulation by maize grown in acidic soil amended with coal combustion products, Fuel, 78 (1999) 179-185. 
[29] F.J. Hingston, Reaction between boron and clays, Aust. J. Soil Res., 2 (1964) 83-95.

[30] J.R. Sims and F.T. Bingham, Retention of boron by layer silicates, sesquioxides, and soil materials: II. Sesquioxides, Soil Sci. Soc. Am. Proc., 32 (1968) 364-369.

[31] R. Keren, R.G. Gast and B. Bar-Yosef, pH dependent boron adsorption by Na-Montmorillonite, Soil Sci. Soc. Am. J., 45 (1981) 45-48.

[32] R. Keren and U. Mezuman, Boron adsorption by clay minerals using a phenomenological equation, Clays Clay Mineral, 29 (1981) 198-204.

[33] R. Keren and F.T. Bingham, Boron in water, soils and plants, Advances in Soil Science, Vol. 1, Springer-Verlag, New York, 1985, pp. 229-276.

[34] R. Keren and R.G. Gast, pH-dependent boron adsorption by Montmorillonite hydroxi aluminum com-plexes, Soil Sci. Soc. Am. J., 47 (1983) 11161121.
[35] I.D. Rhoades, B. Krueger and M.J. Reed, Laboratory determination of leachable soil boron, Soil Sci. Soc. Am. J., 32 (1968) 643-647.

[36] N. Petric, V. Martinac, M. Labor and M. MirosevicAnzulovic, Isothermal and activated sintering of magnesium oxide from sea water, Mater. Chem. Phys., 53 (1998) 83-87.

[37] M.G. Valyashko, Genesis and exploration of borate deposits related to marine salt deposits, Internat. Geol. Rev., 12 (1970) 711-719.

[38] T.D. Aksenova, V.I. Borisenkov and V.A. Dorofeyeva, Stability of natural magnesium borates in marine brine at various stages of halogenesis, Geochem. Internat., 26 (1989) 31-39.

[39] A. Vengosh, A. Starinsky, Y. Kolodny, A.R. Chivas and M. Raab, Boron isotope variations during fractional evaporation of sea water: new constraints on the marine vs. nonmarine debate, Geology, 20 (1992) 799-802. 